\title{
Association of polymorphisms of physiological candidate genes with phenotype and estimated breeding values of reproductive and growth traits in Thai indigenous chickens
}

\author{
J. Tenzin ${ }^{1,3}$, V. Chankitisakul ${ }^{1}$ and W. Boonkum ${ }^{1,2}$ \\ ${ }^{1}$ Department of Animal Science, Faculty of Agriculture, Khon Kaen \\ University, Khon Kaen, Thailand \\ ${ }^{2}$ Research and Development Network Center for Animal Breeding (Native \\ Chicken), Khon Kaen University, Khon Kaen, Thailand \\ ${ }^{3}$ Department of Animal Science, College of Natural Resources, Royal \\ University of Bhutan, Lobesa, Punakha, Bhutan \\ Corresponding author: W. Boonkum \\ E-mail: wboonkum@gmail.com
}

Genet. Mol. Res. 19 (1): gmr18504

Received October 15, 2019

Accepted January 11, 2020

Published February 29, 2020

DOI http://dx.doi.org/10.4238/gmr18504

\begin{abstract}
Signal transducers and activators of transcription (STAT5B), dopamine receptors D2 (DRD2), bone morphogenetic protein (BMP15), and melatonin receptors type $\mathrm{C}(M T N R 1 C)$ play an important role in growth and reproductive traits in chickens. We studied the $9^{\text {th }}$ generation of 93 Pradu Hang Dam and 95 Chee chickens examining PCR-restriction fragment length polymorphisms to genotype for growth and reproductive traits. There was no significant association between other traits, but we confirmed that in Pradu Hang Dam, DRD2 was associated with egg weight at the age at first egg while $B M P 15$ was associated with egg weight at 300 days and body weight at 300 days. Moreover, MTNRIC was associated with egg weight at 300 days and egg number at 300 days. In Chee, MTNRIC was associated with egg number at 300 days. We suggest that DRD2, BMP15, and MTNRIC be used to select for early maturity and growth, while MTNRIC be used for egg number in Pradu Hang Dam. In Chee, MTNRIC can be a marker to improve egg
\end{abstract}


production. For improving the egg production in Thai native chickens, we recommend that MTNR1C be used in marker-assisted selection.

Key words: PCR-RFLP; STAT5B; DRD2; BMP15; MTNR1C; Marker-assisted selection

\section{INTRODUCTION}

Thai Pradu Hang Dam and Chee chickens are important for sustainable utilization of chicken breeds for egg and meat production in Thailand. They are uniquely suitable and adapted to harsh local environmental conditions and they are comparatively resistant to diseases (Duangjinda, 2015). However, their production performance is low compared to typical commercial breeds (Jaturasitha et al., 2008; Duangjinda, 2015). Therefore, there is a need to improve economically important production traits in these native chickens.

Reproductive and growth traits are the most important economic traits for the poultry industry and are controlled by multiple genes (Ou et al., 2009). Consequently, understanding the genetic networks influencing reproductive and growth traits is important in selecting animals for superior growth and reproductive performance (Zhao et al., 2012). With advances in molecular genetics and its application in genetic improvement programs, polymorphism of candidate genes can be used to help select for complex traits of economic importance (Dekkers et al., 2002), facilitating the use of genetic markers for marker-assisted selection for identification, mapping and analyzing quantitative trait loci (Stone et al., 2005).

Signal transducers and activators of transcription (STATs) represent a family of latent cytoplasmic proteins that mediate a variety of peptide hormones and cytokines in a target cell (Darnell, 1997), controlling the action of growth hormones on target genes (Argetsinger et al., 1996). Ou et al. (2009) have suggested that STAT5B regulates ovary development and sexual maturation. Moreover, in another study, STAT5B knock-out mice had no breast development or lactation (Udy et al., 1997). Dopamine is a neurotransmitter synthesized in the central nervous system (CNS) and involved in the regulation of numerous physiological processes, including endocrine and reproduction processes in humans (Beaulieu et al., 2011). Sartsoongnoen et al. (2008) reported that dopamine might influence the regulation of the reproductive system in Thai chickens. Also, in birds, dopamine inhibited the secretion of vasoactive intestinal peptide (VIP) and prolactin in the pituitary gland, thereby influencing reproductive traits in birds (Youngren et al., 1998). The bone morphogenetic protein 15 (BMP15) is one of the members of the transforming growth factors $-\beta$ (TGF- $\beta$ ) that are involved in numerous development processes (Chang et al., 2002). A gene knockout experiment in mice confirmed that the animals are fertile, albeit with a change in folliculogenesis (Yan et al., 2001). Moreover, BMP15 is associated with increased ovulation rate, litter size and sterility in sheep and goats (Javanmard et al., 2011). In chickens, Han et al. (2015) have reported that BMP15 influences ovary development and sexual maturation (Han et al., 2015). Melatonin is an indole hormone that is synthesized from serotonin in the pineal gland and regulates biological functions through three different receptors subtypes - MTNR1A, MTNR1B and MTNR1C. The different melatonin receptor subtype transcripts are characterized in domestic chickens and are equivalent to the 
melatonin receptors in the brain; expression suggests that it influences the reproduction of domestic chickens (Sundaresan et al., 2009). In birds, melatonin also regulates neuroendocrine functions, feeding patterns, circadian rhythms and hibernation (Ayre et al., 1992; Adachi et al., 2002). Melatonin is also present in ovarian follicular fluid, suggesting an ovarian function (Li et al., 2013).

In this context, the objective of this study was to investigate the association between candidate genes and phenotypes and determine estimated breeding values of growth and reproductive traits in Thai Pradu Hang Dam (PD) and Chee (CH) chickens.

\section{MATERIAL AND METHODS}

\section{Ethical consideration}

This study was approved by Institutional Animal Care and Use Committee (IACUC) reference number, Khon Kaen University, Khon Kaeen, 4002, Thailand.

\section{Sample and phenotypic traits}

The traits recorded for this study were body weight of the hens at 14 weeks (BW14), body weight at age at first egg (BWAFE), BW300 (body weight at 300 days), egg weight at age of first egg (EWAFE), egg weight at 270 days (EW270), egg weight at 300 days (EW300), age at first egg (AFE), egg number at 270 days (EN270) and egg number at 300 days (EN300). The chickens were provided by the Research and Development Network Centre for Animal Breeding (NCAB) (Native Chicken) at Khon Kaen University, Khon Kaen 40002, Thailand. The chickens were reared in separate cages; water and commercial standard ration were provided ad libitum. At 300 days, $1.5 \mathrm{~mL}$ of blood were collected from the wing vein from a random sample of 93 Pradu Hang Dam (PD) and and 95 Chee (CH) chickens; $100 \mu \mathrm{L}$ of ethylenediaminetetraacetic acid (EDTA) was used as an anticoagulant.

\section{Genotyping by PCR-RFLP}

Genotyping was performed via PCR-Restriction Fragment Length Polymorphism (PCR-RFLP). The DNA was extracted using a modified form of guanidine hydrochloride, as described by Goodwin et al. (2011). The DNA fragments were amplified by PCR using a mixture with a total volume of $10 \mu \mathrm{L}$, containing $1 \mu \mathrm{L} 100 \mathrm{ng}$ of genomic DNA, $1 \mu \mathrm{L}$ of 1 $\mathrm{mM}$ dNTPs (Promega, USA), $1 \mu \mathrm{L}$ of 10X PCR buffer, $1 \mu \mathrm{L} 3 \mathrm{mM}$ of forward and reverse primer, $0.1 \mu \mathrm{L} 5 \mathrm{U}$ DNA polymerase (RBC Bioscience, Taiwan) and deionized water. The characteristics of the primers for STAT5B (Ou et al., 2009; Sadeghi et al., 2012), DRD2 (Xu et al., 2011), BMP15 (Huang et al., 2015) and MTNR1C (Li et al., 2013) are shown in Table 1. The PCR conditions were as follows: initial denaturation at $95^{\circ} \mathrm{C}$ for $5 \mathrm{~min}, 30$ cycles of denaturation at $95^{\circ} \mathrm{C}$ for $45 \mathrm{~s}$, annealing temperature for $30 \mathrm{~s}$ (Table 1), extension for $45 \mathrm{~s}$, final extension at $72^{\circ} \mathrm{C}$ for $5 \mathrm{~min}$, followed by a cooling period of $1 \mathrm{~min}$ at $25^{\circ} \mathrm{C}$. The PCR products were detected via electrophoresis, using $2 \%$ agarose gel and a SynGene photography system (SynGene, UK). Restriction digestion was performed using $6.8 \mu \mathrm{L}$ of deionized water, $1 \mu \mathrm{L} \mathrm{10X}$ tango buffer, $0.2 \mu \mathrm{L}$ of restriction enzymes (Table 1 ) and $2 \mu \mathrm{L}$ 
of the PCR products. The fragments were separated using $2 \%$ agarose gel electrophoresis, and the genotypes were identified using a gel documentation system (SynGene, UK).

\begin{tabular}{|c|c|c|c|c|}
\hline Genes & Primer 5'-3' & Ta $\left({ }^{\circ} \mathrm{C}\right)$ & PCR Size (bp) & Enzyme \\
\hline STAT5B & $\begin{array}{l}\text { F: TGGAGCTACTGGCATCTCTCA } \\
\text { R: TGCTGCAGTTGCTGTGGTCT }\end{array}$ & 68 & 514 & HhaI \\
\hline DRD2 & $\begin{array}{l}\text { F: TGCACATAAAAGCCCACTCACTG } \\
\text { R: GCCTGAGCTGGTGGGGGG }\end{array}$ & 68 & 248 & $B S e G I$ \\
\hline BMP15 & $\begin{array}{l}\text { F: GGGTTTTAGCCCTGATCTTGCACTC } \\
\text { R: ATCACCCATTGCCACCACCTTACCT }\end{array}$ & 68 & 517 & Alw21I \\
\hline MTNR1C & $\begin{array}{l}\text { F: GGTGTATCCGTATCCTCTAA } \\
\text { R: GACAGTGGGACAATGAAGT }\end{array}$ & 60 & 386 & MboI \\
\hline
\end{tabular}

Ta - annealing temperature

\section{Statistical analysis}

Gene and genotype frequencies were calculated according to Falconer et al. (1996). The chi-square goodness of fit was used to test for Hardy Weinberg equilibrium, using the software package SAS 9.2 (SAS Institute Inc., Cary, NC, USA). Breeding values were estimated using Best Linear Unbiased Prediction (BLUP) with a single trait

$$
y=X \beta+Z a+\varepsilon
$$

where $y=$ vector of observed values, $\beta=$ vector of fixed effect of hatch and age at first egg (AFE), $a=$ vector of additive gene effect of each animal, $\varepsilon=$ Error. The variables $\mathrm{X}$ and $\mathrm{Z}$ are incidence matrices relating the observations to the respective fixed and direct genetic effects, respectively. Marker-trait association was performed using the following general linear model (GLM) of SAS 9.2 (SAS Institute Inc., Cary, NC, USA):

$$
Y_{i j}=\mu+G_{i}+H_{k}+e_{i j}
$$

where $Y_{i j}$ is the estimated breeding value of different production traits, $\mu$ is the overall population mean, $G_{i}$ is the effect of each genotype, $\mathrm{H}_{\mathrm{k}}$ is the fixed effect of the hatch and $e_{i j}$ is the residual error. Type III sum of square was used for the F-test, and Tukey-Kramer's multiple range tests was used to test the significant differences in least square means; a $p$ value of $\leq 0.05$ was considered statistically significant.

\section{RESULTS}

\section{Genotyping by PCR-RFLP and genotype frequencies}

The restriction fragments of SNP C4535156T STAT5B for C and T alleles were $411 / 102 \mathrm{bp}$ and $513 \mathrm{bp}$. For DRD2, the alleles C and T had fragment sizes of $248 \mathrm{bp}$ and $196 \mathrm{bp}$, for SNP C231T of BMP15 had fragment lengths of C and T alleles at 271/170 bp and 347/170 bp, and for MTNR1C, the alleles A and G had fragment lengths of $372 \mathrm{bp}$ and 333 bp, respectively. The gene frequencies in both Pradu Hang Dam and Chee chickens 
deviated from the Hardy-Weinberg equilibrium, except for DRD2 (Table 2). Allele frequencies of less than $2 \%$ were excluded from further analysis.

Table 2. Genotype and allele frequencies of STAT5B, DRD2, BMP15 and MTNR1C in Pradu Hang Dam (PD) and Chee (CH) chickens.

\begin{tabular}{|c|c|c|c|c|c|c|c|c|}
\hline \multirow{2}{*}{ Genes } & \multirow{2}{*}{ Genotype } & \multicolumn{3}{|c|}{ Frequency (N) } & \multicolumn{4}{|c|}{$\chi^{2}$} \\
\hline & & PD & CH & Alleles & PD & CH & PD & CH \\
\hline \multirow{3}{*}{ STAT5B } & $\mathrm{CC}$ & $0.83(77)$ & $0.36(34)$ & $\mathrm{C}$ & 0.89 & 0.57 & $165.71 *$ & $6.07 *$ \\
\hline & $\mathrm{CT}$ & $0.11(10)$ & $0.41(39)$ & $\mathrm{T}$ & 0.11 & 0.43 & - & - \\
\hline & TT & $0.06(6)$ & $0.23(22)$ & - & - & - & - & - \\
\hline \multirow{3}{*}{ DRD2 } & $\mathrm{CC}$ & $0.24(22)$ & $0.72(68)$ & $\mathrm{C}$ & 0.50 & 0.85 & 0.1 & $113.97 *$ \\
\hline & $\mathrm{TC}$ & $0.51(47)$ & $0.27(26)$ & $\mathrm{T}$ & 0.50 & 0.15 & - & - \\
\hline & TT & $0.26(24)$ & $0.01(1)$ & - & - & - & - & - \\
\hline \multirow{3}{*}{ BMP15 } & $\mathrm{CC}$ & $0.03(3)$ & $0.98(93)$ & $\mathrm{C}$ & 0.31 & 0.99 & $29.97 *$ & $269.23 *$ \\
\hline & $\mathrm{CT}$ & $0.54(50)$ & 0.01 (1) & $\mathrm{T}$ & 0.69 & 0.01 & - & - \\
\hline & TT & $0.43(40)$ & 0.01 (1) & - & - & - & - & - \\
\hline \multirow{3}{*}{ MTNR1C } & AA & $0.06(6)$ & $0.07(7)$ & A & 0.27 & 0.20 & $45.52 *$ & $91.65^{*}$ \\
\hline & $\mathrm{AG}$ & $0.40(37)$ & $0.25(24)$ & G & 0.73 & 0.80 & - & - \\
\hline & GG & $0.54(50)$ & $0.67(64)$ & - & - & - & - & - \\
\hline
\end{tabular}

* Significant deviation of the gene and genotype frequency from Hardy-Weinberg Equilibrium at $\mathrm{P}<0.05$.

\section{Association of candidate genes with estimated breeding values of production traits (EBV data)}

The descriptive statistics of the data used in the study is presented in Table 3 . The average body weight at 300 days for $\mathrm{CH}$ chickens was 1,772.32 \pm 163.51 grams whereas for PD, it was $2071.4 \pm 243.48$ grams. The PD were heavier than $\mathrm{CH}$ chickens. Moreover, the egg weight at 300 days (EW300) was higher in PD than $\mathrm{CH}$ at $47.08 \pm 4.24$ and $43.00 \pm$ 3.88 grams, respectively. However, the first egg was produced by $\mathrm{CH}$ earlier (187 days) than by PD (207 days). Subsequently, at 300 days a greater number of eggs were produced by $\mathrm{CH}$ than $\mathrm{PD}$, producing $70.52 \pm 17.04$ and $65.39 \pm 13.99$ eggs, respectively.

For Thai Pradu Hang Dam chickens, the association between estimated breeding values of egg production traits and candidate gene is presented in Table 4.

Table 3. Descriptive statistics of data used in the association study of Pradu Hang Dam (PD) and Chee $(\mathrm{CH})$ chicken genes, presented as mean and standard deviation.

\begin{tabular}{|c|c|c|c|c|c|c|c|c|c|}
\hline Breed/Traits & Mean & SD & Min & Max & Breed/Traits & Mean & SD & Min & Max \\
\hline $\mathrm{CH}$ & $\mathrm{n}=95$ & & & & PD & $\mathrm{n}=93$ & & & \\
\hline BW14 & 925.68 & 82.06 & 760 & 1230 & BW14 & $1,112.47$ & 96.65 & 910 & 1350 \\
\hline BWAFE & $1,681.58$ & 135.95 & 1,350 & 2,130 & BWAFE & $2,058.39$ & 222.48 & 1,600 & 2,600 \\
\hline BW300 & $1,772.32$ & 163.51 & 1,450 & 2,250 & BW300 & 2071.4 & 243.48 & 1,600 & 2,900 \\
\hline EWAFE & 35.49 & 3.31 & 23 & 42 & EWAFE & 41.33 & 3.70 & 31 & 49 \\
\hline EW270 & 40.72 & 2.74 & 33 & 47 & EW270 & 44.49 & 3.71 & 36 & 56 \\
\hline EW300 & 43.00 & 3.88 & 36 & 51 & EW300 & 47.08 & 4.24 & 38 & 61 \\
\hline AFE & 187.96 & 16.08 & 154 & 229 & AFE & 207.33 & 17.60 & 158 & 260 \\
\hline EN270 & 53.97 & 14.29 & 24 & 96 & EN270 & 46.33 & 12.68 & 9 & 88 \\
\hline EN300 & 70.52 & 17.04 & 24 & 118 & EN300 & 65.39 & 13.99 & 28 & 109 \\
\hline
\end{tabular}

SD Standard deviation, BW14, body weight in grams at 14 weeks, BWAFE, body weight in grams at age at first egg, BW300, body weight in grams at 300 days, EWAFE, egg weight in grams at age at first egg, EW270, egg weight in grams at 270 days, EW300, egg weight in grams at 300 days, AFE, age at first egg, EN270, egg number at 270 days, EN300, egg number at 300 days. 
Table 4. Association of STAT5B, DRD2, BMP15 and MTNR1C with estimated breeding values of egg production traits in Pradu Hang Dam (PD) and Chee (CH) chickens.

\begin{tabular}{|c|c|c|c|c|c|c|}
\hline Breed/Genes & Genotype & EWAFE (g) & EW270 (g) & EW300 (g) & EN270 (count) & EN300 (count) \\
\hline \multicolumn{7}{|l|}{ PD } \\
\hline & $\mathrm{CC}$ & $-0.01 \pm 0.01$ & $0.23 \pm 0.52$ & $-0.02 \pm 0.05$ & $0.21 \pm 0.90$ & $-0.35 \pm 0.78$ \\
\hline \multirow[t]{2}{*}{ STAT5B } & CT & $-0.01 \pm 0.02$ & $0.02 \pm 0.96$ & $-0.08 \pm 0.10$ & $-0.64 \pm 1.64$ & $-0.56 \pm 1.45$ \\
\hline & $\mathrm{TT}$ & $-0.03 \pm 0.03$ & $-0.41 \pm 1.20$ & $-0.17 \pm 0.12$ & $-0.66 \pm 2.10$ & $-1.51 \pm 1.83$ \\
\hline \multirow[t]{3}{*}{ DRD2 } & $\mathrm{CC}$ & $-0.04 \pm 0.02^{\mathrm{a}}$ & $-0.54 \pm 0.85$ & $-0.09 \pm 0.09$ & $-0.56 \pm 1.48$ & $-1.14 \pm 1.29$ \\
\hline & $\mathrm{TC}$ & $-0.00 \pm 0.02^{\mathrm{b}}$ & $0.76 \pm 0.64$ & $-0.01 \pm 0.06$ & $-0.82 \pm 1.11$ & $-0.82 \pm 0.97$ \\
\hline & TT & $-0.00 \pm 0.02^{b}$ & $-0.37 \pm 0.83$ & $-0.17 \pm 0.08$ & $0.28 \pm 1.45$ & $-0.47 \pm 1.26$ \\
\hline \multirow[t]{3}{*}{ BMP15 } & $\mathrm{CC}$ & $-0.03 \pm 0.04$ & $-0.84 \pm 1.47$ & $-0.31 \pm 0.15^{\mathrm{a}}$ & $-0.65 \pm 2.56$ & $-2.58 \pm 2.23$ \\
\hline & $\mathrm{CT}$ & $-0.01 \pm 0.02$ & $-0.20 \pm 0.63$ & $0.06 \pm 0.06^{\mathrm{ab}}$ & $-0.61 \pm 1.11$ & $-0.37 \pm 0.96$ \\
\hline & TT & $0.00 \pm 0.01$ & $0.88 \pm 0.57$ & $0.10 \pm 0.06^{\mathrm{c}}$ & $0.16 \pm 0.99$ & $0.53 \pm 0.86$ \\
\hline \multirow[t]{3}{*}{ MTNR1C } & AA & $-0.00 \pm 0.02$ & $1.53 \pm 1.00$ & $0.11 \pm 0.10^{\mathrm{a}}$ & $-0.08 \pm 1.75$ & $-0.13 \pm 1.51$ \\
\hline & AG & $-0.02 \pm 0.02$ & $-0.64 \pm 0.75$ & $-0.18 \pm 0.08^{\mathrm{b}}$ & $-0.74 \pm 1.32$ & $-1.51 \pm 1.14$ \\
\hline & GG & $-0.02 \pm 0.02$ & $-1.05 \pm 0.83$ & $-0.20 \pm 0.08^{b}$ & $-0.28 \pm 1.46$ & $-1.04 \pm 1.26$ \\
\hline \multicolumn{7}{|l|}{$\mathrm{CH}$} \\
\hline \multirow[t]{3}{*}{ STAT5B } & $\mathrm{CC}$ & $-0.00 \pm 0.00$ & $-0.22 \pm 0.14$ & $-0.32 \pm 0.30$ & $0.00 \pm 0.00$ & $0.00 \pm 0.00$ \\
\hline & $\mathrm{CT}$ & $0.00 \pm 0.00$ & $0.08 \pm 0.14$ & $0.09 \pm 0.30$ & $0.00 \pm 0.00$ & $0.00 \pm 0.00$ \\
\hline & TT & $0.00 \pm 0.00$ & $0.04 \pm 0.17$ & $-0.03 \pm 0.35$ & $0.00 \pm 0.00$ & $0.00 \pm 0.00$ \\
\hline \multirow[t]{3}{*}{ MTNR1C } & AA & $0.00 \pm 0.00$ & $-0.12 \pm 0.27$ & $-0.25 \pm 0.57$ & $0.00 \pm 0.00$ & $0.01 \pm 0.00^{\mathrm{a}}$ \\
\hline & AG & $0.00 \pm 0.00$ & $0.07 \pm 0.15$ & $0.10 \pm 0.32$ & $0.00 \pm 0.00$ & $0.00 \pm 0.00^{\mathrm{b}}$ \\
\hline & GG & $-0.00 \pm 0.00$ & $-0.04 \pm 0.09$ & $-0.12 \pm 0.19$ & $-0.00 \pm 0.00$ & $-0.00 \pm 0.00^{\mathrm{b}}$ \\
\hline
\end{tabular}

Egg weight at age at first egg, EW270, egg weight at 270 days, EW300, egg weight at 300 days, EN270, egg number at 270 days, EN300, egg number at 300 days; values with different letters within the same column are significantly different at $\mathrm{P}<0.05$.

The DRD2 showed a significant association between estimated breeding value at egg weight at the age at first egg (EWAFE) (P < 0.05), while MTNR1C and BMP15 showed a significant association between the estimated breeding value of egg weight at 300 days (EW300) $(\mathrm{P}<0.05)$. Further, there was a significant association between the estimated breeding value (EBV) of body weight (BW300) days and BMP15 $(\mathrm{P}<0.05)$ (Table 5).

Table 5. Association of estimated breeding values of growth traits and genes in Pradu Hang Dam (PD) and Chee $(\mathrm{CH})$ chickens.

\begin{tabular}{llccc}
\hline Breed/Genes & Genotype & BW14 (g) & BWAFE $(\mathbf{g})$ & BW300 $(\mathbf{g})$ \\
\hline PD & & & $-0.02 \pm 0.09$ & $-0.12 \pm 0.20$ \\
& CC & $1.23 \pm 4.20$ & $0.02 \pm 0.17$ & $-0.07 \pm 0.37$ \\
STAT5B & CT & $4.81 \pm 7.82$ & $-0.22 \pm 0.21$ & $-0.17 \pm 0.12$ \\
& TT & $12.43 \pm 9.81$ & $-0.06 \pm 0.15$ & $-0.38 \pm 0.33$ \\
CRD2 & CC & $10.07 \pm 6.93$ & $-0.06 \pm 0.11$ & $-0.42 \pm 0.24$ \\
& TC & $5.93 \pm 6.77$ & $-1.29 \pm 0.56^{\mathrm{a}}$ \\
BMP15 & TT & $5.27 \pm 11.97$ & $-0.39 \pm 0.26$ & $-0.21 \pm 0.24^{\mathrm{b}}$ \\
& CC & $7.36 \pm 5.18$ & $0.07 \pm 0.11$ & $0.15 \pm 0.22^{\mathrm{b}}$ \\
MTNR1C & CT & $5.83 \pm 4.63$ & $0.10 \pm 0.10$ & $0.14 \pm 0.38$ \\
& TT & $9.52 \pm 8.15$ & $0.16 \pm 0.18$ & $-0.70 \pm 0.29$ \\
CH & AA & $2.48 \pm 6.15$ & $-0.19 \pm 0.13$ & $-0.79 \pm 0.32$ \\
STAT5B & AG & $6.46 \pm 6.80$ & $-0.19 \pm 0.14$ & $4.55 \pm 14.49$ \\
& GG & & $3.45 \pm 14.23$ \\
MTNR1C & CC & $0.02 \pm 0.02$ & $-0.98 \pm 7.32$ & $3.03 \pm 16.73$ \\
& CT & $0.02 \pm 0.02$ & $3.38 \pm 7.18$ & $15.15 \pm 26.98$ \\
& TT & $0.05 \pm 0.02$ & $9.88 \pm 8.44$ & $-9.17 \pm 15.05$ \\
\hline
\end{tabular}

Body weight at 14 weeks, BWAFE, body weight at age at first egg, BW270, body weight at 270 days, BW300, body weight at 300 days. Values with different letters within the same column are significantly different at $\mathrm{P}<0.05$. 
However, there was no association between breeding values of egg production traits with STAT5B (Table 4), and no other genes were associated with growth traits (P $<0.05$; Table 5). In Chee chickens, we observed a significant association of MTNR1C with estimated breeding values of egg number at 300 days $(\mathrm{P}<0.05$; Table 4). However, there was no association between EBV of egg production traits and STAT5B. In addition, there was no significant association with the EBVs of growth traits with STAT5B and MTNR1C genes (Table 5).

\section{Association of candidate genes with growth and reproductive traits (phenotypic data)}

In Pradu Hang Dam chickens, BMP15 was significantly associated with egg weight at 270 days (EW270), while MTNR1C showed a significant association with egg number at 270 and 300 days $(\mathrm{P}<0.05$; Table 6$)$.

Table 6. Association of STAT5B, DRD2, BMP15 and MTNR1C with egg production traits in Pradu Hang Dam (PD) and Chee $(\mathrm{CH})$ chickens.

\begin{tabular}{lllllll}
\hline Breed/Traits & Genotype & EWAFE $(\mathbf{g})$ & EW270 $(\mathbf{g})$ & EW300 $(\mathbf{g})$ & EN270 $($ count) & EN300 (count) \\
\hline PD & & & & & & \\
& CC & $40.32 \pm 0.76$ & $43.79 \pm 0.77$ & $46.08 \pm 0.90$ & $49.60 \pm 2.55$ & $69.63 \pm 2.86$ \\
STAT5B & CT & $42.31 \pm 1.41$ & $45.23 \pm 1.43$ & $47.81 \pm 1.67$ & $48.41 \pm 4.74$ & $68.23 \pm 5.31$ \\
& TT & $40.67 \pm 1.78$ & $43.01 \pm 1.79$ & $45.76 \pm 2.09$ & $44.70 \pm 5.95$ & $65.99 \pm 6.67$ \\
DRD2 & CC & $42.12 \pm 1.25$ & $44.32 \pm 1.26$ & $46.05 \pm 1.48$ & $46.66 \pm 4.20$ & $67.40 \pm 4.71$ \\
& TC & $40.96 \pm 0.94$ & $43.82 \pm 0.95$ & $46.55 \pm 1.11$ & $50.21 \pm 3.15$ & $68.80 \pm 3.53$ \\
& TT & $40.23 \pm 1.22$ & $43.90 \pm 1.23$ & $47.05 \pm 1.44$ & $45.85 \pm 4.10$ & $67.65 \pm 4.60$ \\
BMP15 & CC & $38.44 \pm 2.17$ & $41.17 \pm 2.18^{\mathrm{a}}$ & $44.71 \pm 2.55$ & $51.42 \pm 7.25$ & $72.20 \pm 8.13$ \\
& CT & $42.51 \pm 0.94$ & $45.63 \pm 0.94^{\mathrm{b}}$ & $44.97 \pm 1.10$ & $44.34 \pm 3.14$ & $65.10 \pm 3.52$ \\
MTNR1C & TT & $42.36 \pm 0.84$ & $45.23 \pm 0.84^{\mathrm{b}}$ & $46.97 \pm 0.99$ & $46.95 \pm 2.80$ & $66.55 \pm 3.14$ \\
& AA & $41.85 \pm 1.47$ & $45.42 \pm 1.49$ & $46.60 \pm 1.74$ & $50.85 \pm 4.94^{\mathrm{a}}$ & $72.29 \pm 5.54^{\mathrm{a}}$ \\
CH & AG & $40.83 \pm 1.11$ & $43.59 \pm 1.12$ & $46.52 \pm 1.31$ & $49.62 \pm 3.73^{\mathrm{a}}$ & $69.65 \pm 4.18^{\mathrm{a}}$ \\
STAT5B & GG & $40.63 \pm 1.23$ & $43.03 \pm 1.24$ & $45.53 \pm 1.45$ & $42.25 \pm 4.12^{\mathrm{b}}$ & $61.91 \pm 4.62^{\mathrm{b}}$ \\
& & & & & & \\
& CC & $35.85 \pm 0.67$ & $41.01 \pm 0.55^{\mathrm{a}}$ & $43.45 \pm 0.79$ & $49.33 \pm 2.91$ & $66.65 \pm 3.50$ \\
MTNR1C & CT & $35.52 \pm 0.66$ & $39.97 \pm 0.54^{\mathrm{a}}$ & $42.57 \pm 0.78$ & $52.18 \pm 2.86$ & $68.93 \pm 3.44$ \\
& TT & $36.60 \pm 0.78$ & $41.53 \pm 0.63^{\mathrm{b}}$ & $44.16 \pm 0.91$ & $53.61 \pm 3.36$ & $69.57 \pm 4.04$ \\
& AA & $36.34 \pm 1.25$ & $40.47 \pm 1.02$ & $43.46 \pm 1.47$ & $46.30 \pm 5.42$ & $63.83 \pm 6.52$ \\
\hline
\end{tabular}

Egg weight at age at first egg, EW270, egg weight at 270 days, EW300, egg weight at 300, EN270, egg number at 270 days, EN300, egg number at 300 days; values with different letters within one column are significant at $\mathrm{P}<0.05$.

There was no significant association between candidate genes and body weight in Pradu Hang Dam chickens (Table 7).

However, in Chee chickens, a statistically significant association was found between STAT5B and egg weight 270 (EW270) days (P < 0.05; Table 6). However, there was no significant association with MTNR1C and egg production traits (Table 6). Also, we observed no association with candidate genes and growth traits (Table 7). 


\begin{tabular}{|c|c|c|c|c|}
\hline Breed/Genes & Genotype & BW14 (g) & BWAFE (g) & BW300 (g) \\
\hline \multicolumn{5}{|l|}{ PD } \\
\hline & $\mathrm{CC}$ & $1,110.95 \pm 20.39$ & $2,031.07 \pm 46.18$ & $2,039.78 \pm 49.94$ \\
\hline \multirow[t]{3}{*}{ STAT5B } & СT & $1,106.67 \pm 37.92$ & $2,019.26 \pm 85.91$ & $1,992.54 \pm 92.90$ \\
\hline & TT & $1,184.99 \pm 47.60$ & $2,123.55 \pm 107.85$ & $2,234.25 \pm 116.63$ \\
\hline & $\mathrm{CC}$ & $1,132.18 \pm 33.62$ & $2,026.51 \pm 76.17$ & $2,048.43 \pm 82.37$ \\
\hline \multirow[t]{3}{*}{ DRD2 } & $\mathrm{TC}$ & $1,140.73 \pm 25.19$ & $2,029.39 \pm 57.06$ & $2,068.54 \pm 61.71$ \\
\hline & TT & $1,129.70 \pm 32.83$ & $2,117.99 \pm 74.37$ & $2,149.61 \pm 80.43$ \\
\hline & $\mathrm{CC}$ & $1,133.95 \pm 58.06$ & $1,942.10 \pm 131.54$ & $1,975.68 \pm 142.24$ \\
\hline \multirow[t]{3}{*}{ BMP15 } & CT & $1,139.70 \pm 25.11$ & $2,114.56 \pm 56.89$ & $2,144.73 \pm 61.52$ \\
\hline & TT & $1,128.95 \pm 22.44$ & $2,117.22 \pm 50.84$ & $2,146.16 \pm 54.97$ \\
\hline & AA & $1,144.17 \pm 39.54$ & $2,113 / 85 \pm 89.59$ & $2,140.96 \pm 96.88$ \\
\hline \multirow[t]{2}{*}{ MTNR1C } & AG & $1,139.78 \pm 29.85$ & $2,028.79 \pm 67.64$ & $2,074.18 \pm 73.14$ \\
\hline & GG & $1,118.66 \pm 32.99$ & $2,031.24 \pm 74.74$ & $2,051.43 \pm 80.82$ \\
\hline \multicolumn{5}{|c|}{$2,051.24 \pm 14.14$} \\
\hline \multirow[t]{3}{*}{ TAT5B } & $\mathrm{CC}$ & $901.23 \pm 1653$ & $1,690.75 \pm 27.85$ & $1,782.57 \pm 33.41$ \\
\hline & CT & $938.72 \pm 16.23$ & $1,668.15 \pm 27.34$ & $1,754.62 \pm 32.80$ \\
\hline & TT & $929.37 \pm 19.08$ & $1,717.42 \pm 32.14$ & $1,826.52 \pm 38.56$ \\
\hline \multirow[t]{3}{*}{ MTNR1C } & AA & $927.68 \pm 30.78$ & $1,716.38 \pm 51.84$ & $1,810.20 \pm 62.19$ \\
\hline & $\mathrm{AG}$ & $910.55 \pm 17.17$ & $1,671.91 \pm 28.92$ & $1,777.40 \pm 34.69$ \\
\hline & GG & $931.10 \pm 10.36$ & $1,688.01 \pm 17.45$ & $1,776.10 \pm 20.93$ \\
\hline
\end{tabular}

Body weight (g) of hens at 14 weeks, BWAFE, body weight (g) of hens at age at first egg, BW300, body weight of hens at 300 days.

\section{DISCUSSION}

Indigenous chickens of Thailand such as Chee and Pradu Hang Dam are descended from same ancestor and are closely related to Red Jungle Fowl (Mekchay et al., 2014) and are distinct from commercial lines - Chee is similar to layers and Pradu Hang Dam is related to broilers. Therefore, Chee and Pradu Hang Dam could be promoted for meat and egg purpose, respectively (Dorji et al., 2011). Similarly, this study found that Chee produces greater cumulative egg number than Pradu Hang Dam at 300 days. Therefore, Chee could be promoted for egg while Pradu Hang Dam is better suited for meat production as it attains better growth and weight at 300 days. Therefore, these two breeds are uniquely suited for egg and meat production in Thailand and these indigenous chickens can considerably contribute to egg and meat production. However, they produce lesseggs compared to commercial breeds selected for persistent and high laying rates (Xu et al., 2010). Moreover, their body weight is also low compared to that of commercial breeds (Jaturasitha et al., 2008). However, eggs and meat from native chickens are preferred and more expensive than those from commercial ones (Li et al., 2013). Moreover, meat of indigenous chicken is flavorful and tastier after cooking too. In addition, indigenous chickens can be raised relatively at lower cost where the birds can scavenge in the yard. However, they have lower growth rate than commercial broilers (Wattanachant et al., 2004). Thus, the improvement of egg productivity and growth rates is an important component of the selection of chickens for breeding programs (Jaturasitha et al., 2008; Venturini et al., 2013). In this study, production traits and estimated breeding values were used to analyze the marker-trait associations in Chee and Pradu Hang Dam chickens. Estimated breeding values can be used when adjusting for environmental and non-additive genetic effects in evaluating genes for 
more accurate selection (Sadeghi et al., 2012). In Pradu Hang Dam chickens, allele and genotype frequencies deviated significantly from Hardy-Weinberg equilibrium $(\mathrm{P}<0.05)$ except for DRD2 ( $<$ < 0.05), while for Chee chickens, all the genes studied deviated from the Hardy-Weinberg equilibrium $(\mathrm{P}<0.05)$. The disequilibrium may be due to selective breeding, which had been carried out for nine generations.

Phenotypic traits such as egg production and growth traits are controlled by polygenes (Niknafs et al., 2014). STAT5B is activated by differentiation-dependent transcriptional regulation of distinct cytokine signaling pathway components and mediated distinct cytokine signaling pathway components and mediated distinct functional processes in the rat ovary for early follicle growth, atresia and luteinization (Russell et al., 1996; Dajee et al., 1998). They are significant modulators of growth hormone, growth hormone receptor, insulin like growth factor and prolactin and found to be related with growth and reproductive traits. In this study, a significant association was found between egg weight at 270 days with STAT5B, with the $\mathrm{T}$ allele having a higher egg weight than the $\mathrm{C}$ allele. This was similar to a significant association previously found between STAT5B and growth and reproductive traits (Ou et al., 2009; Sadeghi et al., 2012).

Dopamine is neurotransmitter and relates to catecholamines family and transmits impulses between neurons. Their activation happens through dopaminergic receptors, which play an important role in in the regulation of avian physiological and reproductive function (Sartsoongnoen et al., 2008). We found in Pradu Hang Dam chickens that DRD2 was associated with egg weight at first egg (EWAFE), with TC and TT genotypes having higher breeding values than the CC genotype (Table 4). In a similar study, Xu et al. (2011) found a significant association with DRD2 T5841629C SNP and AFE. However, we found no association with growth traits.

BMP15 is a critical factor for normal fertility in female mammals (Fortune, 2003) and it is involved in folliculogenesis and ovary development (Laissue et al., 2006). In chickens, in study, it was expressed higher in ovarian tissues and ovarian follicular growth and development and recruit primordial follicles (Han et al., 2015). We found that BMP15 was associated with the estimated breeding values of egg weight at 300 days (EW300) as well as body weight at 300 days (BW300). Its TT genotype had the highest breeding value for egg weight compared to the other genotypes, while the TT genotype had the highest breeding value for body weight. Huang et al. (2015) reported that the SNP at C34T significantly influenced age at first egg (AFE), egg number and body weight at first egg (BWAFE), while SNP C231T influenced AFE. Also, BMP15 influences sexual maturation and ovary development (Huang et al., 2015).

Melatonin regulates ovarian function through activation of multiple receptors and signaling pathways on different target cell types especially theca and granulosa cells (Wang et al., 2008). The binding site in the chicken ovary is located in the follicular cell layer (Ayre et al., 1992). Sundaresan et al. (2009) described the partial sequences of ovarian melatonin receptors subtypes that had identical profiles with receptors in neural tissues and MTNR1C was found in thecal and granulosa cell layers. These findings suggested that it has downstream cellular function in ovarian tissues. Moreover, we found in Pradu Hang Dam, that the SNP JQ249896:g.294G>A of MTNR1C was associated with breeding values of EW300. Its AA genotype had higher breeding values than the genotypes AG and GG (P $<0.05$ ). In addition, in Chee chickens, the SNP JQ249896:g.294G>A of MTNR1C was associated with estimated breeding values of egg number at 300 days, and the AA genotype 
had higher estimated breeding values for egg number than the other genotypes. This study supports the findings of an earlier study that also characterized ovarian melatonin receptors in chickens, and their expression showed that it influences reproduction and may serve as a genetic marker (Li et al., 2013). Moreover, in Pradu Hang Dam chickens, MTNR1C as significantly associated with egg number at 270 and 300 days for its phenotypic data. This tentative association shows that allele A results in higher egg production in Thai Pradu Hang Dam chickens than allele G. Therefore, we confirm that MTNR1C might be used as genetic marker for improving egg production.

These findings indicate that we may use DRD2, BMP15 and MTNR1C for better reproductive and growth performance in Pradu Hang Dam chickens for a balanced selection, whereas in Chee chickens, we may use MTNR1C to increase egg number. Numerous authors have studied the association of candidate genes with production traits in domestic animals (Rothschild et al., 2000; Cui et al., 2006; Zhang et al., 2018). For example, Cui et al. (2006) found a significant association with the 24-bp indel of prolactin with egg production. A similar study in Pradu Hang Dam chickens by Charoensin (2012) found a significant association between 5FA-PRL, 24BP-PRL VIPR1 and estimated breeding values of egg production traits. However, in Chee chickens, that author found no association with the genetic markers and reproductive traits (Charoensin, 2012). This study supplements earlier studies on the selection of chickens for earlier reproduction and better production. In Thai broilers, cGH and IGF-1 were studied for an association with growth performance and carcass traits and significantly affected growth performance (Anh et al., 2015). Therefore, these functional candidate genes are useful in finding a genetic basis for production traits in domestic animals.

We investigated STAT5B, DRD2, BMP15 and MTNR1C in terms of associations with phenotypic and estimated breeding values of growth and reproductive traits in Thai Pradu Hang Dam and Chee chickens. Based on our results, DRD2, BMP15 and MTNR1C may be used as genetic markers for a balanced selection, based on the promising associations between those genes and production traits in Pradu Hang Dam chickens. Similarly, MTNR1C may be used as a genetic marker for improving egg production in Chee chickens. Further studies are needed on native chickens of the Southeast Asian region, as the chickens were shown to be related to Thai native Chickens, which originated from Red Jungle Fowl.

\section{ACKNOWLEDGMENTS}

We would like to thank the Thailand International Cooperation Agency (TICA) for providing funding for this research. We also would like to extend our gratefulness to the Research and Development Network Centre for Animal Breeding (Native Chickens), Khon Kaen University, Khon Kaen, Thailand, for help in data collection and management. We are grateful to the Animal Genomic Laboratory for providing laboratory facilities and support.

\section{CONFLICTS OF INTEREST}

The authors declare no conflict of interest. 


\section{REFERENCES}

Adachi A, Natesan AK, Whitfield-Rucker MG, Weigum SE, et al. (2002). Functional melatonin receptors and metabolic coupling in cultured chick astrocytes. Glia. 39(3): 268-278.

Anh NTL, Kunhareang S, and Duangjinda M (2015). Association of chicken growth hormones and insulin-like growth factor gene polymorphisms with growth performance and carcass traits in Thai broilers. Asian. Austral. J. Anim. 28(12): 1686-1695. doi:10.5713/ajas.15.0028.

Argetsinger L, and Carter-Su (1996). Growth hormone signalling mechanisms: involvement of the tyrosine kinase JAK2. Horm. Res. Paediatr. 45(Suppl. 1): 22-24. doi:10.1159/000184823

Ayre E, Yuan H and Pang S (1992). The identification of 125I-labelled iodomelatonin-binding sites in the testes and ovaries of the chicken (Gallus domesticus). J. Endocrinol. 133(1): 5-11. doi:10.1677/joe.0.1330005.

Beaulieu J-M and Gainetdinov RR (2011). The physiology, signaling, and pharmacology of dopamine receptors. Pharmacol. Rev. 63(1): 182-217. doi:10.1124/pr.110.002642.

Chang H, Brown CW and Matzuk MM (2002). Genetic analysis of the mammalian transforming growth factor- $\beta$ superfamily. Endocr. Rev. 23(6): 787-823. doi:10.1210/er.2002-0003.

Charoensin S (2012). Detection of genetic marker associated with egg production traits in Pradu Hang Dam and Chee chicken. Master's thesis. Khon Kaen University, Khon Kaen. Available at [https://opac.kku.ac.th/Catalog/BibItem.aspx?BibID=b00364249].

Cui J-X, Du H-L, Liang Y, Deng X-M, et al. (2006). Association of polymorphisms in the promoter region of chicken prolactin with egg production. Poult. Sci. 85(1): 26-31. doi:10.1093/ps/85.1.26.

Dajee M, Fey GH, and Richards JS (1998). Stat $5 b$ and the orphan nuclear receptors regulate expression of the $\alpha 2-$ macroglobulin ( $\alpha 2 \mathrm{M})$ gene in rat ovarian granulosa cells. Mol. Endocrinol. 12(9): 1393-1409. doi:10.1210/mend.12.9.0161.

Darnell JE (1997). STATs and gene regulation. Science. 277(5332): 1630-1635. doi:10.1126/science.277.5332.1630.

Dekkers JC, and Hospital F (2002). The use of molecular genetics in the improvement of agricultural populations. Nat. Rev. Genet. 3(1): 22-32. doi:10.1038/nrg701.

Dorji N, Daungjinda M and Phasuk Y (2011). Genetic characterization of Thai indigenous chickens compared with commercial lines. Trop. Anim. Health. Prod. 43(4), 779-785.

Duangjinda M (2015). Breeding Strategies for Improvement of Global Traits in Thai Indigenous Chicken. Paper presented at the Proceeding International Seminar Improving Tropical Animal Production For Food Security.

Falconer DS, Mackay TF and Frankham R (1996). Introduction to quantitative genetics. $4^{\text {th }}$ edn. Oliver and Boyd, Edinburgh and London.

Fortune J (2003). The early stages of follicular development: activation of primordial follicles and growth of preantral follicles. Anim. Reprod. Sci. 78(3-4): 135-163. doi:10.1016/S0378-4320(03)00088-5.

Goodwin W, Linacre A and Hadi S (2011). An introduction to forensic genetics (Vol. 2): John Wiley Sons.

Han H, Lei Q, Zhou Y, Gao J, et al. (2015). Association between BMP15 gene polymorphism and reproduction traits and its tissues expression characteristics in chicken. PLoS One. 10(11): e0143298. doi:10.1371/journal.pone.0143298.

Huang H, Liang Z, Li S, Li C, et al. (2015). Polymorphism identification in BMP15 and GDF9 genes and their association with egg production in chickens. Br. Poult. Sci. 56(3): 277-283. doi:10.1080/00071668.2015.1019829.

Jaturasitha S, Kayan A and Wicke M (2008). Carcass and meat characteristics of male chickens between Thai indigenous compared with improved layer breeds and their crossbred. Arch. Tierzucht. 51(3): 283-294.

Jaturasitha S, Srikanchai T, Kreuzer M and Wicke M (2008). Differences in carcass and meat characteristics between chicken indigenous to northern Thailand (Black-boned and Thai native) and imported extensive breeds (Bresse and Rhode Island Red). Poult. Sci. 87(1): 160-169. doi:10.3382/ps.2006-00398.

Javanmard A, Azadzadeh N and Esmailizadeh AK (2011). Mutations in bone morphogenetic protein 15 and growth differentiation factor 9 genes are associated with increased litter size in fat-tailed sheep breeds. Vet. Res. Commun. 35(3): 157-167. doi:10.1007/s11259-011-9467-9.

Laissue P, Christin-Maitre S, Touraine P, Kuttenn F, et al. (2006). Mutations and sequence variants in GDF9 and BMP15 in patients with premature ovarian failure. Eur. J. Endocrinol. 154(5): 739-744. doi:10.1530/eje.1.02135.

Li D, Zhang L, Smith D, Xu H, et al. (2013). Genetic effects of melatonin receptor genes on chicken reproductive traits. Czech. J. Anim. Sci. 58(2): 58-64. doi:10.17221/6615-CJAS.

Mekchay S, Supakankul P, Assawamakin A, Wilantho A, et al. (2014). Population structure of four Thai indigenous chicken breeds. BMC genet. 15(1): 15-40.

Niknafs S, Javaremi AN and Sadeghi M (2014). Single nucleotide polymorphisms in BMPR-IB and STAT5B genes and their association with growth and reproductive traits in chicken. Songklanakarin J. Sci. Technol. 36(2).

Ou J, Tang S, Sun D and Zhang Y (2009). Polymorphisms of three neuroendocrine-correlated genes associated with growth and reproductive traits in the chicken. Poult. Sci. 88(4): 722-727.

Rothschild M, Messer L, Day A, Wales R, et al. (2000). Investigation of the retinol-binding protein 4 (RBP4) gene as a candidate gene for increased litter size in pigs. Mamm. Genome. 11(1): 75-77. doi:10.1007/s003350010015. 
Russell DL, Norman RL, Dajee M, Liu X, et al. (1996). Prolactin-induced activation and binding of stat proteins to the IL-6RE of the $\alpha 2$-macroglobulin $(\alpha 2 \mathrm{M})$ promoter: relation to the expression of $\alpha 2 \mathrm{M}$ in the rat ovary. Biol. Reprod. 55(5): 1029-1038. doi:10.1095/biolreprod55.5.1029.

Sadeghi M, Niknafs S, Shahrbabak HM and Fatemi S (2012). Two SNP in STAT5B gene and their association with breeding value of growth and egg production traits in Mazandaran Indigenous Chicken. Livest. Sci. 147(1): 198202. doi:10.1016/j.livsci.2012.04.015.

Sartsoongnoen N, Kosonsiriluk S, Prakobsaeng N, Songserm T, et al. (2008). The dopaminergic system in the brain of the native Thai chicken, Gallus domesticus: Localization and differential expression across the reproductive cycle. Gen. Comp. Endocrinol. 159(1): 107-115. doi:10.1016/j.ygcen.2008.08.002.

Stone R, Casas E, Smith T, Keele J, et al. (2005). Identification of genetic markers for fat deposition and meat tenderness on bovine chromosome 5: development of a low-density single nucleotide polymorphism map. J. Anim. Sci. 83(10): 2280-2288. doi:10.2527/2005.83102280x.

Sundaresan N, Leo MM, Subramani J, Anish D, et al. (2009). Expression analysis of melatonin receptor subtypes in the ovary of domestic chicken. Vet. Res. Commun. 33(1): 49-56. doi:10.1007/s11259-008-9071-9.

Udy GB, Towers RP, Snell RG, Wilkins RJ, et al. (1997). Requirement of STAT5B for sexual dimorphism of body growth rates and liver gene expression. Proc. Natl. Acad. Sci. U. S. A. 94(14): 7239-7244. doi:10.1073/pnas.94.14.7239.

Venturini GC, Savegnago RP, Nunes BN, Ledur MC, et al. (2013). Genetic parameters and principal component analysis for egg production from White Leghorn hens. Poult. Sci. 92(9): 2283-2289. doi:10.3382/ps.2013-03123.

Wang Y, Peng K-M, Li J-L, Song H, et al. (2008). Ultrastructure and melatonin 1a receptor distribution in the ovaries of African ostrich chicks. Cytotechnology. 56(3): 187-195. doi:10.1007/s10616-008-9147-y.

Wattanachant S, Benjakul S and Ledward D (2004). Composition, color, and texture of Thai indigenous and broiler chicken muscles. Poult. Sci. 83(1): 123-128.

Xu H, Shen X, Zhou M, Fang M, et al. (2010). The genetic effects of the dopamine D1 receptor gene on chicken egg production and broodiness traits. BMC Genet. 11: 17-17. doi:10.1186/1471-2156-11-17.

Xu H, Zeng H, Luo C, Zhang D, et al. (2011). Genetic effects of polymorphisms in candidate genes and the QTL region on chicken age at first egg. BMC Genet. 12(1): 33. doi:10.1186/1471-2156-12-33.

Yan C, Wang P, DeMayo J, DeMayo FJ, et al. (2001). Synergistic roles of bone morphogenetic protein 15 and growth differentiation factor 9 in ovarian function. Mol. Endocrinol. 15(6): 854-866.

Youngren O, Chaiseha Y and El Halawani ME (1998). Regulation of prolactin secretion by dopamine and vasoactive intestinal peptide at the level of the pituitary in the turkey. Neuroendocrinology. 68(5): 319-325. doi:10.1159/000054380.

Zhang S, Cui H and Su Y (2018). FSH $\beta$ gene polymorphism and correlation between it and egg production performance in Leizhou black duck. Nanfang Nongye Xuebao. 49(1): 142-147.

Zhao X, Wang J, Zhang G, Wei Y, et al. (2012). Single nucleotide polymorphism in the STAT5b gene is associated with body weight and reproductive traits of the Jinghai Yellow chicken. Mol. Biol. Rep. 39(4): 4177-4183. 